Instructions for authors, subscriptions and further details:

\title{
http://generos.hipatiapress.com
}

\section{Sexual Harassment in a Higher Education Institution}

Renán Jesús García-Hernández ${ }^{1}$

Julita Elemí Hernández-Sánchez ${ }^{1}$

Verónica García-Martínez ${ }^{1}$

1) Universidad Juárez Autónoma de Tabasco

Date of publication: October 25th, 2020

Edition period: October 2020 - February 2021

To cite this article: García-Hernández, R. J., Hernández-Sánchez, J. E., García-Martínez, V. (2020). Sexual Harassment in a Higher Education Institution. Multidisciplinary Journal of Gender Studies, 9(3), 210-233. doi: 10.17583/generos.2020.5609

To link this article: http://dx.doi.org/10.17583/generos.2020.5609

\section{PLEASE SCROLL DOWN FOR ARTICLE}

The terms and conditions of use are related to the Open Journal System and to Creative Commons Attribution License (CC-BY). 


\title{
Sexual Harassment in a Higher Education Institution
}

Renán Jesús García-Hernández

Universidad Juárez Autónoma de Tabasco

Julita Elemí Hernández-Sánchez

Universidad Juárez Autónoma de Tabasco

Verónica García-Martínez

Universidad Juárez Autónoma de Tabasco

\begin{abstract}
Sexual harassment is a type of gender violence, which is generally naturalized and rarely reported. The aim of this qualitative study was to analyze the experiences of female university students who have been victims of sexual harassment. The intentional sample consisted of 10 participants between the ages of 22 and 24 years from a university in the southeast of Mexico. Interviews were analyzed through different categories, such as the perception of the interviewee, about the harassment, the consequences, and facing the event. The analysis was based on the QSR 6 (NVivo) software. It was found that students perceive harassment as something normal and even romantic, but subsequently there are feelings of humiliation and guilt. Those who reported the incident did not obtain help, in all of them there was a feeling of learned helplessness. In addition, harasser professors have a special language to communicate when they want sexual favors: "you have to take an equivalence test", language that the students know and understand.
\end{abstract}

Keywords: sexual harassment, higher education, university, women

2020 Hipatia Press

ISSN: 2014-3613

doi: 10.17583/generos.2020.5609 


\section{Acoso Sexual en una Institución de Educación Superior}

Renán Jesús García-Hernández

Universidad Juárez Autónoma de Tabasco

Julita Elemí Hernández-Sánchez

Universidad Juárez Autónoma de Tabasco

Verónica García-Martínez

Universidad Juárez Autónoma de Tabasco

\section{Resumen}

El acoso sexual es un tipo de violencia de género que es naturalizada y rara vez denunciada. El objetivo de este estudio cualitativo fue analizar las experiencias de estudiantes universitarias víctimas de acoso sexual. La muestra intencional consistió en 10 participantes de entre 22 y 24 años de una universidad del sureste de México. Se realizó un análisis de contenido de entrevistas a través de categorías, como la percepción de la relatora sobre el acoso, sobre las consecuencias del mismo y el afrontamiento. El análisis se realizó usando el software QSR 6 (NVivo). Se observó que las estudiantes perciben el acoso como algo normal e incluso romántico, pero posteriormente existen sentimientos de humillación y culpabilidad. Aquellas que denunciaron el incidente no obtuvieron ayuda, en todas hubo un sentimiento de indefensión aprendida. Asimismo, los profesores acosadores tienen un lenguaje especial para comunicarle a las alumnas cuándo desean favores sexuales, como: "tienes que irte a examen de equivalencia” lenguaje que las estudiantes conocen y entienden

Palabras clave: acoso sexual, educación superior, universidad, mujeres 
ender violence occurs for the simple fact of belonging to a determine sex and it is defined as "behaviors that make evident the inequality in interpersonal relationships, which interpose and sometimes legitimize the control of men over women” (Hernández, Jiménez \& Guadarrama, 2015 p. 65). Some authors mention that the objective of violence is to ensure the submission and control, consequently is consider a symbol of power (Moya \& Expósito, 2005; Nahar, Van Reeuwijk \& Reis, 2013).

Hernández et al. (2015) mention that violence includes rapes, sexual abuse, humiliation, and harassment, which can also happen in the workplace and educational institutions. Sexual harassment is one of many kinds of gender violence and has diverse effects in the people that suffer it. Among the physical consequences are headaches, sleep disorders, hypertension, nausea, etc. The social effects include the difficulty to reach equality, negative consequences over the institutions efficiency, and the condonation of sexual violence.

However, defining sexual harassment cannot be taken lightly, according to Gillander \& Stein (2017) "there is no single definition of sexual harassment in the international literature” (p. 2). Even though there are diverse definitions depending on the approximation, different authors agree that it is a situation where a negative psychological situation is experienced, and has as origin a non-desired sexual behavior, which can be felt as offensive or threatening, and happens mainly in labor or academic environments (Topa, Morales \& Depolo, 2007).

In the educational context, this kind of violence involves unwanted sexual behavior, which interferes with the right to receive an equal educational opportunity (Miller \& Mondschein, 2017), this is evident in cases where the harasser is a teacher and the victim a student. In this situation, the harasser uses his superior hierarchical level over a subordinate, and the victim is in disadvantage with his/her grades depending on the harasser. Instead, when the harassment happens between equals, like among classmates, the harasser may not affect the academic condition of the victim directly.

Either way, both situations are problems of great proportions, for their consequences can affect the victim in diverse forms, like psychological, to their health, or even in his/her labor or academic productivity. Among the 


\section{García-Hernández, Hernández-Sánchez \& García Martínez \\ - Sexual Harassment in a Higher Education Institution}

problems mentioned, are anxiety, emotional distress, social isolation and even suicide (Hernández, Jiménez \& Guadarrama, 2015).

It is important to mention that both men and women can suffer sexual harassment in different contexts (Organización Internacional del Trabajo, 2019; Street, Gradus, Stafford, \& Kelly, 2007; U.S. Equal Employment Opportunity Commission, 2019). However, women are who suffer it mostly because of the inequality in which most of them live in the world, and it is a violation of their human rights, like: the right to life and security, and most importantly to dignity.

In Mexico, the importance of the problem was noticed in the National Survey on Domestic Relationships Dynamic 2016 (Instituto Nacional de Estadística y Geografía, 2018), in which was reported that $66 \%$ of women above 15 years old had suffered at least one event of violence, weather it is physical, sexual, emotional, economical, or discrimination. However, it is believed that the problem could be of a larger dimension, as it's mentioned by Silva (2011), the registered cases are just the ones denounced, but it can be assumed that the frequency of this kind of behavior could be larger, for many cases are not denounced or properly detected. According to Vélez \& Baca (2011) the victims of sexual harassment don't sue because they fear to be blamed, or they don't know where to report the situation, and even when they try to sue, most times, it doesn't apply for lack of evidence.

In addition, how harassment is perceived, depends on economic, social and cultural aspects, and it could be seen as something normal within a culture (Benites, 2012). Mexican culture is described as based on men superiority over women. Díaz-Guerrero (2004) mentions the values and beliefs of the Mexican family that validate men's authority and supremacy, while women are portrayed as submissive and obedient.

Mexican cultural values are based in what Díaz-Guerrero (2004) named socio-cultural premises of the Mexican family, which are reflected in popular sayings, proverbs, and adages. From those, Díaz Guerrero extracted the prevalent norms and beliefs from the fifties and grouped them in five factors: tradition, honor, virginity, affiliate obedience and machismo. In this last factor, the author mentioned that machismo in Mexican culture is presumed as, the total dominance of men over women, on sexual potency and quarrelsome virility (Díaz-Guerrero, 1970). While women were perceived as 
submissive, men were perceived as being of a strong sexual nature, therefore, a man was perceived as more masculine depending on how sexually active he was.

Nowadays, Mexico is in a process of cultural change, but the traditional cultural values are still accepted (Díaz-Loving \& Cubas-Carlín, 1991; Hernández \& Vargas, 2015;Rocha, 2008). Even though there are laws that guarantee the equality of the sexes, and progress has been made in diverse fronts to achieve gender equity, this change has not fully been reached, in part because these cultural values mentioned above determine how men and women behave. The ideology represented in this socio cultural premises of the Mexican family, has been mentioned as one of the factors that encourage harassment (Vélez \& Baca, 2011), which in many occasions is perceived as normal and natural behavior.

Unfortunately, if within traditional Mexican culture, men are valued for their sexual potency and women for their abnegation, it could be considered natural that men would try to "seduce" as many women as they could, without caring about the way it happens. Also, if machismo in Mexican culture socializes women to be submissive and abnegated, this can negatively influence their response against sexual harassment. They may not respond assertively or even, due to the confusion generated by this cultural context, sexual harassment may be perceived as something natural or with positive connotations.

These sexist cultural values also influence organizations and institutions, becoming places that facilitate and maintain sexual harassment. In this sense, some authors, (Smit \& Du Plessis, 2011) notice that higher educational institutions, can be unsafe places where gender violence has become a common and recurrent practice. According to Wilson (2000) "sexual harassment is not a new problem in universities, but one which mainly women students have always faced. Although a reality of university life, many would like to pretend it is not happening” (p. 171).

Thus, this study was performed with the general objective to analyze, from the socio cultural perspective, the relationships and cultural constructs that generate sexual harassment. 


\section{García-Hernández, Hernández-Sánchez \& García Martínez - Sexual Harassment in a Higher Education Institution}

\section{Method}

The type of method used in this study was qualitative with a relational analytic design. This methodological and theoretical approach, allowed the analysis and comprehension of experiences of being object of sexual harassment, from the point of view of the participants. Specifically, a biographic approach was used (Legrand, 1993), where the narratives are considered a way to reach the individual and personal meanings of experiences (Correa, 1999). With this approach, the deep exploration of experiences allows a way to comprehend social realities (Sharim, 2001).

\section{Participants}

Initially, the sample was obtained through the educational psycho diagnosis departments of several academic divisions of a university located in the southeastern part of Mexico. It was asked to the coordinators of each department if they had any female students that had been victims of sexual harassment, and to ask their permission to be interviewed. It was emphasized that the interviews were confidential and only to be used for a research project. Afterwards, the snowball sampling technique was used (Patton, 2002), which allowed to find more participants through invitations of the students. However, because of the student's great resistance to talk about the subject, the final sample consisted of 10 students, between 22 and 24 years old from diverse careers. The minimal quantity of 12 participants proposed by Cornejo, Mendoza \& Rojas (2008) was not reached. However, because of the theoretical saturation criteria, it was considered that the sample was large enough. Even though all participants mentioned to have suffered sexual harassment, they also mentioned a teacher as the perpetrator; therefore, their experiences are about the kind where the aggressor is situated in a higher hierarchical level.

\section{Procedure}

Thematic life histories were done, understood as a narration about life from the perspective of the subject that lived it (Cornejo, 2006), in this case, about the sexual harassment experience. These were taken in the offices of the 
Psycho Diagnosis Department of each academic division and the same person interviewed in all sessions. Permission was asked to record the interviews, once granted, the stories were taped. It be specified, that the University's Bioethical Committee approved this study and the names of the participants were changed to ensure confidentiality.

\section{Information Analysis}

The recordings were transcribed using the QSRN6 software, in which a content analysis was performed, after making categorizations through the Mind Manager software. From the whole story's analysis, central categories and analysis axis about sexual harassment were developed. Triangulation processes were applied to give more reliability to the determination and relevance of these categories, this is important because there was a pondering over the particular ideas of each researcher and how these could influence the way to approach the material (Etherington, 2004). The main categories analyzed from the interviews were:

(1) Subjective perception of the storyteller: Defined as the perception over the harassment situation. In addition, perceived harassment severity levels were defined, according to the levels proposed by the National Women's Institution (Instituto Nacional de las Mujeres, n/d), in which, the low level of sexual harassment is distinguished by being verbal, the medium level is nonverbal without physical contact, and the high level of sexual harassment is distinguished by being verbal with physical contact.

(2) The storyteller's perception over the sexual harassment's consequences on their physical, psychological and academic state: Is portrayed as the meaning given by each participant to what happens after the living experience.

(3) Mechanism / Plan of Action: In this category, it was analyzed the way in which harassment was presented, in other words, the mechanic used by the harassers to commit harassment.

(4) Facing the event: It refers to the cognitive and behavioral processes that are developed to face demands considered as excessive or exorbitant to a person's resources (Lazarus \& Folkman, 1986). 


\section{García-Hernández, Hernández-Sánchez \& García Martínez \\ - Sexual Harassment in a Higher Education Institution}

\section{Results}

The information shows that sexual harassment is not perceived as such until its severity increases, and causes a learned feeling of helplessness in the women who had suffered it (Seligman, 1975). This generates discouragement feelings by watching that there is no possibility to change what is affecting them. A demotivation state is manifested, and in some way, resignation towards the situation, they perceive themselves as unable to modify what is happening to them or they feel ashamed, also they do not know how to face the useless and overwhelming institutional inertia.

\section{Subjective Perception Over the Sexual Harassment}

It can be noticed in the stories, that the harassment can be perceived in the beginning as a sentimental relationship, at times even of a paternal type with the harasser, who is seen as a respect figure. In addition, the sexist cultural value given to women's submission hinders them to perceive the harassment as such. The preconceptions about the teacher's role and the student's need of a paternal figure make the harassment a frustrating situation for the victim that is difficult to detect and confront.

...Either way, he touched me, he started to caress my face, it felt good, but I never thought that would happen, in a way I saw him as a paternal figure. (Student 3).

Then, everything was going well, until later. It went like that many times that he gave me a lift home and all that, and I started trusted him, because he was older, I never saw any malice on him. (Student 6).

Until the harassment's severity level increases, there is an inability, to perceive the harassment as such, or the difference between the harassment and the exchange of consented love behaviors.

...The same situation doesn't let you know what to do, because you don't know if he is to be trusted, like..., he said he wouldn't do it, that nothing was happening, then I thought - well, he isn't doing anything..., or is he? (Student 6). 


\section{GÉNEROS -Multidisciplinary Journal of Gender Studies, 9(3) 218}

I thought I liked it, because I was well treated to some point, but then he started talking about sexual intercourse, that he would protect me, that I needed to check out my period date, and asking when we could meet again. That we could get lost for three days. (Student 4)

The sexual harassment becomes common and daily while being a low level of harassment, distinguished by the looks and uncommon approaches, but then increases until higher levels.

Then it turned worse, like when he walked he rubbed me..., but it wasn't a rub, ..., more like he passed his hand through my behind, through my..., but. But now he was more daring, he pinched me, ... you know... my bubs, or he touched my butt cheeks, or with his foot he reached mine under the table. I didn't know what to do. He always sought for me. He kept with all his touching. (Student 2).

The event's severity increases while becoming common and routine for the teacher, as the school cycle progresses. It is evident that harassment events have a dynamic that goes from low to medium and then high or severe, until it becomes something that the victim cannot handle.

When we were talking, he touched me lightly, like..., he always grasped my legs while making his hand gestures and movements, so I made a surprised or scared look in my face, coming from an older person you doubt if it's a good thing. Then he already started with the leg touching and you feel (shocked), we met outside, so we talked and he started to get closer, I never thought bad of him, but then he introduced his hand and I cried. (Student 2).

By not being able to get out of the harassment situation, the victim exercises a self-criticism and refers the fact as something negative in which she has been useless:

This is one of my worse mistakes! then it happened again, but not as severe. (Student 4). 


\section{García-Hernández, Hernández-Sánchez \& García Martínez - Sexual Harassment in a Higher Education Institution}

The student is within a dynamic, in which the harasser turns her into his property and limits her social, and even labor life, sometimes using threats.

And then I greeted him, and when my classmates were coming he said Now you are only going to be with me. See why I don't want you to hang out with others? If you get together with them, you'll regret it. (Student 6)

About the severe harassment situations, the reactions are of deep rejection, even for the act itself as well as for the perpetrator, however, it ends by accepting, falling in the impotence or helplessness.

You know..., at the end... I had to accept it... I died of disgust. Only by remembering it I feel sick... but I couldn't say no to him, there was my research in the middle and my scholarship and also my husband. It was horrible, I wanted to die, I just wanted him to be done so I could leave. (Student 4).

\section{Perception About the Consequences}

Harassment brings consequences for the victim, as pointed by CastañoCastrillón et al. (2010) who mention diverse studies that have documented how the abusive episodes affect negatively the confidence and intimate disposition, also mentioning the mental health sequels on short, medium and long-term, and generating posttraumatic stress, depression, anxiety, chronic irritability, drug abuse, suicidal tendencies and eating disorders.

The persistence of the harassment becomes a psychological torment with psychosomatic and social effects (Leymann, 1996).

Well, I couldn't do it again, I stayed away from him and didn't want to be with him, or near him. I felt awful, I feared my husband could find out, I almost didn't sleep. I was getting sick of many things. I had headaches and stomach aches. I was desperate because he was also looking after my thesis, in which I had a scholarship. One day I was speaking to my ex academic advisor and when she asked about my thesis, I couldn't help it, and told her what was happening. (Student 4) 
The consequences of the event are not only for a short term but also for the long term.

When I remember it I feel bad. At first I used to see if maybe I did something that triggered his behavior, but I don't know, I try not to think about it. By example, I already know that I will feel sick today. Also I feel guilty. (Student 5)

Consequences are not only psychological, but also on schoolwork because some teachers fulfill their threats.

Of course it disfavored me, instead of moving forward to other courses I had to sign up again to the failed one. They prejudice the students a lot, it does not help, because you can't advance, then he said that I failed his course, and I answered that it was fine, no problem! But of course it angers you, I failed his course and I didn’t complain. (Student 5).

... And I felt impotent at that time, it was bad because he acted normal afterwards, and I cried again, felt like the world crumbled, you lose hope in your teachers and then you get fixated with the situation, you get confused. (Student 2).

... But it does scare you, like..., because he is the teacher, then you are like..., what if he doesn't help me anymore? What if he lies saying that my work is wrong or something? (Student 3).

\section{Mechanism and Plan of Action}

The harassment begins with the creation of an ambient of trust from the perpetrator. He attempts to gain the victim's trust since the course starts.

I had all my trust on my teacher, at the beginning he was very cool, besides establishing a good teacher - student relationship, he also tried to establish a friendship with us, in several occasions we were invited to hang out with them and they helped us a lot. I never thought he would do that to me. (Student 5). 


\section{García-Hernández, Hernández-Sánchez \& García Martínez - Sexual Harassment in a Higher Education Institution}

Then slowly I started to get alone with him, because he also assigned us a project in which he didn't explained enough about it. As I had the need to know about this assignment, well I started meeting him and trusting him, right? (Student 3).

It is also evident that the perpetrator seeks situations in which the harassment could be explained by labor or academic reasons.

Well he got near us, like his body very close to us, uh. When you noticed, he was already behind you with his body against yours or really close. Also, he would grab your hand and for him it was like he was explaining something related to the class. He did that to all of us, I talked with the others and he was doing all of it to 5 students. (Student 1).

In addition, harassment has become so common that the same teachers use a special language, a term they use to refer to the act of intercourse with them, when the teacher wants to have sex with the student he tells her that she has to do an "equivalence".

Well, I'm sorry for you, but you know what's the equivalence, that's how some of them disguise it, like if you were asking for a course that has an equivalence for other, they named it like that, the equivalence... The equivalence means to sleep with them, they say it in code. (Student 5).

\section{Facing the Event}

After the event, weather the perpetrator has reached his goal or the victim has refused to his demands, hiding is a strategy that follows, fitting as an escape or a way to avoid a direct confrontation to the situations (Folkman, Lazarus, Schetter, DeLongis \& Gruen, 1986). In this kind of facing, the person does not feel able to change what is happening, and uses her cognitive processes to diminish the emotional distress in a way that avoids, minimizes, or keeps herself away of negative situations. In our storytellers, we found this kind of facing, for there are emotional manifestations, and they avoided future interaction with the harasser. 


\section{GÉNEROS -Multidisciplinary Journal of Gender Studies, 9(3)}

No, I don't want my husband to find out, I never told him. After I finished my thesis I rested, I never visited him again, didn't talk to him, not at all, like nothing ever happened. (...) Also, I tried to not go by myself, like the thesis was of two students, I was always going with my classmate and the teacher couldn't say a thing. (Student 5).

Because when I saw it was him again for another course, I took it out and waited for the next semester, then I checked if it was a different teacher to sign up to the course. I used to go back home all disappointed and my sister asked me: Why are you so sad? And I told her nothing, only answered that I was just bored. And I never made a single comment to my family because they could be willing to come to the university and make a circus out of it, why would I tell them? I thought, better solve it like that, and it stayed that way. (Student 2).

At analyzing this item, it can be noticed that the perpetrator feels confident and comfortable with the whole situation, he does not feel guilt or repent, even worse, he does not fear to be sued. In fact, as it was explained before, they even have their own term to refer to the sexual intercourse with the student, which is an "equivalence" to the approval of the course. Their dynamic is to gain the trust of the student and escalate to the next level, until he reaches threats, coercion and blackmail. In the other side, the students, at the beginning they trust the teacher, and justify the harassment behavior as something friendly, in cases even seeing him as a parental figure, but then all that turns into feelings of fear, despair, guilt and hopelessness. They fear that their families will find out, so they hide the sexual harassment, almost all times without formally denouncing it.

In this analysis, we could see that only 2 of the 10 students dared to seek for help of peers or people foreign to the university's administration and they received emotional support and empathy, in one case even coming from the former academic advisor of the interviewed.

... I thought that if I said something no one would believe me, but she did, she told me to not do a thing, that she would fix it. She knew him well. I think they use to be classmates or something. I don't know how she did it, but he didn't bother me anymore. (Student 5). 


\section{García-Hernández, Hernández-Sánchez \& García Martínez - Sexual Harassment in a Higher Education Institution}

My classmates, well, they decided to type a letter asking to remove the teacher and we all signed it, then... Also, they were telling me that I should sue him, that I shouldn't keep quiet, or that I stop him, that I should ask him why he's getting so close like that, they were guiding me. (Student 3).

However, the answers from the institution are not that solidary, for there is a re-victimization process distinguished by the production of forms to stigmatize or to not respect the victim's distress or rights. This comes as a new impact to the victim, by example, not believing or questioning the victim's statement, having to prove her affectation in an un-trusted environment, the criminalization of the victim that has to justify why it happened to her, or the banalization of pain and suffering, by minimizing it without considering the victim's situation. Another negative factor happens when the victims are asked to give their statement repeatedly. Berinstain (1999) points out, that the re-victimization is the one that derives from the relationship between the victim and the penal system, and involves the clash of the victim's legit expectations and the institutional reality. Students face legal voids and taboos; the student knows that her complaint will end up weather in believing the teacher or her.

Well, we were interviewed, one at the time, to ask us what had happened, and they jumped to the conclusion that the student that entered the letter deserved to be expelled, for being a troublemaker or to be slandering the teacher, they changed my friend to another area. (Student 3).

Because it ain't the first time that they do this to me, later they explained that I'm too susceptible to manipulation, I told them my experience and they said I'm easily manipulated because it had happened other times before. (Student 7).

I'm afraid because I've been told the teacher is in the syndicate and is protected by it, and that he has connections with other teachers. The truth is that I have a friend that went badly in a similar problem, she told on a teacher that was charging for grades, the teacher was asking her for money in exchange of a good score, and she ended up arguing with teachers that had nothing to do with the problem. 


\section{GÉNEROS -Multidisciplinary Journal of Gender Studies, 9(3)}

Because of that, I'm afraid, he has a good relationship with the principal, so I don't know. (Student 6).

After the event, the victim experiences feelings of guilt, then the perpetrator justifies the harassment, blaming it on the victim instead of feeling guilty himself, as someone who only reacts to provocations, and the victim as someone who deserves or provokes this violence. As happens frequently, the victims themselves, and even the people surrounding them, distort the responsibility in a similar way, exaggerating the victim's participation (by example, for going to a certain place, or for not obeying), and by that, exacerbating her feeling of guilt, and indirectly or involuntarily, justifying the aggressor (Puglisi, 2012).

This is one of my worst mistakes, then it happened again, but not as severe, and I thought I liked him, I didn’t denounce, out of guilt. The truth is, I let it happen so it was also my fault. How could I sue if I let it happen too? (Student 4).

The behavior that the victim presents to the harassment attacks, happen in several forms. In occasions the reaction is distinguished by a resignation, which is a sign of impotence to react positively. Things are let as they are, nothing is done, which shows a state of learned hopelessness. In general, the situation is not denounced:

No. I don't want my husband to find out, I never told him. After I finished my thesis I rested, I never visited him again, didn’t talk to him, not at all, like nothing ever happened. I think I'm over it, I don't want to repeat it again. (Student 5).

Well, you don't say a thing, instead you hold it because he is explaining..., but afterwards how the other question you, one by one, and maybe out of shame or for not wanting to make a huge deal out of it, you don't say what it really is, but you change the situation and therefore is not achieved... The people, women sometimes, out of shame or for not wanting any trouble, don't want to say what is really happening to them or what they are feeling. (Student 1 ).

No, not really, I've always solved this kind of problems in my own way, because here you can't complain, is a waste of time, there's no school law or regulation, 


\section{García-Hernández, Hernández-Sánchez \& García Martínez - Sexual Harassment in a Higher Education Institution}

well there is but nobody follows it... I failed his course, I got a bad grade and I didn't say a thing. (Student 3).

Noooo, I didn't talk, not even to my family, because they would come here to complain and I didn't want any trouble, I thought, why would I want to get into trouble?, it is better to stay like this. (Student 6)

You can go tell on the teacher, but they don't do a thing, they tell you..., that's a problem and they don't want any problems. (Student 4).

\section{Discussion}

Within the gender violence context, harassment tends to be seen as something normal and as an example of violence against women. For that, it can be noticed the following:

(1) Victims that suffer gender violence situations do not consider them as sexual aggressions until the harassment is too advanced, in addition to this lack of recognition there's a lack of denounces.

(2) Social beliefs are product of socialization, which blame the victims and exculpate men, such as, that the victims provoked the situations, or that are perpetrated by men with mental pathologies, or that men cannot avoid their sexual needs (Aguilar et al., 2009). In the same sense, Castro and Vázquez (2008) have established that violence suffered by students "is an expression of a social project of domestication that starts early in their lives; and that increases within the institution, when students are gradually learning to bow under the rules of men's dominance” (p. 588).

In addition, it is part of the relationship models that favor gender violence and that answer to relationship schemes distinguished by aspects of dependence and acceptance of abuse, confusing it with love of romantic traditional ideals (Aguilar et al., 2009).

Within gender violence, it can be said that sexual harassment in the higher educational institutes is an example of the permanent hostile environment in which women live. University is an example of an institution 
where an adverse environment is generated against women by normalizing violence forms against them inside the classrooms. In addition, there is the lack of denounces because the students anticipate a lack of support from the university and fear not being taken seriously (Aguilar et al., 2009).

The results confirm several theories. When it comes to higher educational settings, sexual harassment does not respect contexts, ages, or social classes. Victims can be married or single, and even when the harassment starts in the classroom, it can escalate to other settings or contexts.

In general, it starts with low violence, such as looks and approaches to then escalate to higher levels of violence, like touching, handles, pinches, even reaching rape through coercion, pressure or threats. At the beginning, the perpetrator starts gaining the victim's trust, slowly escalating his sexual advances. Also, when the victim answers with a rotund negative, there could be direct negative consequences against her, such as a bad course grade or ignoring the student.

This means psychological violence, which is frequently presented, causing, not only, mental health issues to the victim, like depression, low selfesteem, learned hopelessness, but also these can turn into psychosomatic problems, threatening physical health. The persistence of the harassment situation becomes a psychological torture with social and psychosomatic effects.

Sexual violence comes accompanied by psychological violence, for the not welcoming sexual approaches that also come from a higher ranked person, cause in the victim feelings of humiliation, isolation, impotence, devaluation, etc. Sexual violence is an expression of power abuse, which implicates men's supremacy over women by degrading them and conceived them as objects. As it is mentioned by Castaño-Castrillón et al. (2010), abusive episodes affect negatively the confidence and intimate disposition, besides the low, medium and long-term effects on the victim's mental health.

In the presented cases, even when there was a solidarity ethic (Pino \& Pino, 2007) this was on function to the perception of the participants over their own experience and possible consequence. It seems that these pacts happen when the participants perceive themselves with the possibility of helping, without affecting their own well-being, whether for being in the same position of power, or for hiding between the group members. When this is not the case, they retreat, tell or point out the person involved. 
In our interviewees, it was found that re-victimization is common where the institutional system victimizes the person again, making her repeat the experience or stigmatizing or not respecting the person.

In addition, there is a feeling of guilt that usually comes with the victims, many times reinforced, weather by the victimizer or by the victim's lack of knowledge or experience that think that "perhaps they did something" to provoke the perpetrator, or even the same society that assigns the responsibility on the victim, (Why is she dressing like that?, Why did she go to that place?, etc) then justifying the aggressor, whether indirectly or involuntary (Puglisi, 2012).

Also, it is notorious the lack of the institution's involvement, and as mentioned by Castro \& Vázquez (2008), "they know that in front of the harassment from classmates, teachers, or university workers, is usually convenient to react with extreme caution or plain complicity” (p. 608).

The denounce gets blocked, when a brotherhood among the teachers is created, it discourages students, because they fear, that if they proceed against a teacher, another one would retaliate. Also, there's a total un-knowledge of the processes and protocols, or the lack of them.

In addition, violence is seen as something "normal”, Aguilar et al. (2009) mention that the same victims that suffer violence, do not consider it as a sexual aggression, hence the lack of denounces, also there are social beliefs that blame the victim and exonerate the aggressor.

Evidence was found of what Castro \& Vázquez (2008) call "domestication". They mention that:

Violence that students suffer is an expression of a social project of domestication that begins early in their lives, way before they enter the institution; and that increases inside it, when students gradually learn to bow to the rules of male dominance. (p. 588)

Harassment, generally comes along with apparently sweet, tender and loving words, that make the harassment or abuse to be confused with love or traditional ideals.

It is necessary that students get trained on how to defend themselves against sexual attacks from people of a higher hierarchical level, as well as the 
same level. It is essential to gift the students with assertiveness skills to repeal these abuses.

Traditional Mexican culture, in special, privileges male supremacy and the abnegation of women, is important to change these traditional values (or un-values) and teach students to defend themselves, and to know their rights and demand justice.

From the institution, is necessary to have procedures (attention protocols) and regulatory instances capable of solving, through an objective way, problems of sexual violence like sexual harassment, in all educational institutes.

Protocols are required to guide the solution process of these problems, from the investigation of the case until the measures of solution. These protocols have to be humane, sensitive to the victim, and above all, objective, not applied by the same people that are partners of the victimizer, preferably an external instance.

It is suggested the existence of an institution or instance that treats these cases, with qualified personal in several areas like, legal, psychological, social work, etc. that perform the required activities, since prevention to intervention, if necessary.

In addition, re-educational courses directed to the teachers are also suggested, that motivate the change of negative cultural values and attitude, towards a gender perspective, avoiding misogyny, homophobia, or any other perspective that could give place to discrimination or violence against certain groups.

At the same time, it is necessary to give to the students an education with gender perspective, make them see which are their rights and their responsibilities, and specially to reinforce the self-esteem and assertiveness of vulnerable groups.

\section{References}

Aguilar, C., Alonso, M.J., Melgar, P., \& Molina, S. (2009). Violencia de género en el ámbito universitario. Medidas para su superación. Pedagogía Social. Revista Interuniversitaria de Pedagogía Social, 16, 85-94.

Benites, M. (2012). La convivencia escolar: una estrategia de intervención en bullying. In L. Benites, J. Carozzo, V. Horna, L. Palomino, C. 
229 García-Hernández, Hernández-Sánchez \& García Martínez

- Sexual Harassment in a Higher Education Institution

Salgado, C. Uribe\& L. Zapata (Eds.): Bullying y convivencia en la escuela. Aspectos conceptuales (pp. 75-104). Lima: Observatorio sobre Violencia y Convivencia en la Escuela.

Berinstain, A. (1999). Criminología y Victimología. Colombia: Leyer

Castaño-Castrillón, J. J., González, E. K., Guzmán, J. A., Montoya, J. S., Murillo, J. M., Páez-Cala, M. L., Parra, L. M., Salazar, T. V., \& Velásquez, Y. (2010). Acoso sexual en la comunidad estudiantil de la Universidad de Manizales (Colombia) 2008. Estudio de corte transversal. Revista Colombiana de Obstetricia y Ginecología, 61(1), 18-27.

Castro, R. \& Vázquez, V. (2008). La universidad como espacio de reproducción de la violencia de género. Un estudio de caso en la Universidad Autónoma Chapingo, México, Estudios Sociológicos, 26(78), 587-616.

Cornejo, M. (2006). El enfoque biográfico: trayectorias, desarrollos teóricos y perspectivas. Psykhe, 15(1), 95-106. doi: 10.4067/S071822282006000100326

Cornejo, M., Mendoza, F. \& Rojas, R. C. (2008). La investigación con relatos de vida: pistas y opciones del diseño metodológico. Psykhe, 17(1), 2939. doi: 10.4067/S0718-222820080001000189

Correa, L. R. (1999). La aproximación biográfica como una opción epistemológica, ética y metodológica. Proposiciones, Ediciones Sur, 29, 1-9.

Díaz-Guerrero, R. (1970). La psicología del Mexicano. Mexico: Editorial Trillas.

Díaz-Guerrero, R. (2004). En las garras de la Cultura. Mexico: Edit. Trillas. Díaz-Loving, R., \& Cubas-Carlín, E. (1991). Sexualidad, género y premisas socio-culturales. Revista de Psicología Social y Personalidad, 7(2), 15-42.

Etherington, K. (2004). Becoming a Reflexive Researcher: Using our selves in research. London: Jessica Kingsley Publishers.

Folkman, S., Lazarus, R., Schetter, C., DeLongis, A., \& Gruen, R. (1986). Dynamics of a stressful encounter: Cognitive appraisal, coping, and encounter outcomes. Journal of Personality and Social Psychology, 50 (5), 992-1003. 
Gillander, K., \& Stein, N. (2017). Do schools normalise sexual harassment? An analysis of a legal case regarding sexual harassment in a Swedish high school. Gender and Education, 1-18. doi: 10.1080/09540253.2017.1396292

Hernández, C., Jiménez, M., \& Guadarrama, E. (2015). La percepción del hostigamiento y acoso sexual en mujeres estudiantes en dos instituciones de educación superior. Revista de La Educación Superior, 44(176), 63-82. doi: 10.1016/j.resu.2015.12.004

Hernández, J. E., y Vargas, M. (2015). Derechos Humanos de las Mujeres Indígenas en México. En Hernández, J. E. (2015). Mujeres Indígenas Derechos Humanos y Desarrollo Sustentable. (3 - 33). México: INMUJERES-CONACYT.

Instituto Nacional de Estadística y Geografía. (2017). Resultados de la Encuesta Nacional sobre la Dinámica de las Relaciones en los Hogares (ENDIREH) 2016. Retrieved from http://www.inegi.org.mx/saladeprensa/boletines/2017/endireh/endire h2017_08.pdf

Instituto Nacional de las Mujeres. (n/d). Protocolo para la atención de casos de hostigamiento y acoso sexual. Gobierno de Coahuila. México.

Lazarus, R. S. \& Folkman, S. (1986). Estrés y procesos cognitivos. Barcelona: Martínez Roca.

Legrand, M. (1993). L'approche biographique: Théorie, clinique [El enfoque biográfico: teoría, clínica]. Paris, Francia: Desclée de Brouwer.

Leymann, H. (1996). The content and development of mobbing at work. European Journal of Work and Organizational Psychology, 5(2), 165-184.

Miller E. M., \& Mondschein, E. S. (2017). Sexual harassment and bullying: Similar, but not the same. What school officials need to know. The Clearing House: A Journal of Educational Strategies, Issues and Ideas, 1-7. doi: 10.1080/00098655.2017.1366799

Moya, M. C., \& Expósito, F. (2005). Violencia de género. Aplicando la psicología social, 201-228.

Nahar, P., Van Reeuwikj, M. \& Reis, R. (2013). Contextualizing sexual harassment of adolescent girls in Bangaldesh. Reproductive health matters, 21(41), 78-86. 
231 García-Hernández, Hernández-Sánchez \& García Martínez

- Sexual Harassment in a Higher Education Institution

Organización Internacional del Trabajo. (2020). El hostigamiento o acoso sexual. Género, salud y seguridad en el trabajo. https://www.ilo.org/wcmsp5/groups/public/---americas/---ro-lima/--sro-san_jose/documents/publication/wcms_227404.pdf

Patton, M. Q. (2002). Qualitative research \& evaluation methods (3a ed.).Thousand Oaks, CA: SAGE.

Pino, R. Del, \& Pino, M. Del. (2007). Hacia la ética de la omisión o el desenmascaramiento de la falsa moral en las organizaciones: mobbing y escenarios conspiracionales. In Peña, F., Ravelo, P., \& Sánchez, S. (Eds.), Cuando el trabajo nos castiga. Debates sobre el mobbing en México. México: Ediciones Eón;UAM-Azcapotzalco;Servicio Europeo de Información sobre el Mobbing.

Puglisi, B. (2012). Las escuelas como escenarios en los que se producen y reproducen violencias contra niños, niñas y adolescentes. Caracas: ILDIS.

Rocha, T. (2008). Cultura de Género y Sexismo: De Díaz Guerrero al posmodernismo. En Díaz, R. Etnopsicología Mexicana: Siguiendo la huella teórica y empírica de Díaz Guerrero. México: Trillas

Seligman, M. E. P. (1982). Indefensión. Madrid: Debate, (Orig. from 1975).

Sharim, D. (2001). Los relatos de vida como herramienta para la investigación y formación clínica. Psykhe, 10(2), 71-76.

Silva, J. (2011). Las quejas de abuso y acoso sexual en primarias públicas del Distrito Federal: Evidencia empírica y recomendaciones para el cambio. Revista Mexicana de Investigación Educativa, 16(51), 10871110.

Smit,D. \& Du Plessis, V. (2011). Sexual harassment in the educational sector. Potchefstroomse elektroniese Regsblad,14 (6), 172-217.

Street, A. E., Gradus, J. L., Stafford, J., \& Kelly, K. (2007). Gender differences in experiences of sexual harassment: Data from a male - dominated environment. Journal of Consulting and Clinical Psychology, 75(3), 464-474. doi: 10.1037/0022-006X.75.3.464

Topa, G., Depolo, M. y Moráles, F. (2007). Acoso laboral: meta-análisis y modelo integrador de sus antecedentes y consecuencias. Psicothema, 19(1), 88-94. 
GÉNEROS -Multidisciplinary Journal of Gender Studies, 9(3) 232

U. S. Equal Employment Opportunity Commission. (2019). Charges alleging sex-based harassment. United States of America: U. S. Equal Employment Opportunity

Commission.

https://www.eeoc.gov/statistics/charges-alleging-sex-basedharassment-charges-filed-eeoc-fy-2010-fy-2019

Vélez, G. \& Baca, N. (2011). Salud sexual y reproductiva y violencia de género: Estudio exploratorio en el sector estudiantil de la UAEM. México: Bonobos Editores.

Wilson, F. (2000). The Social Construction of Sexual Harassment and Assault of University Students. Journal of Gender Studies, 9(2), 171-187. doi: 10.1080/713677982 
233 García-Hernández, Hernández-Sánchez \& García Martínez - Sexual Harassment in a Higher Education Institution

Renán Jesús García-Hernández: Universidad Juárez Autónoma de

Tabasco

E-mail address: rjesus_ghz@hotmail.com

Julita Elemí Hernández-Sánchez: Universidad Juárez Autónoma de Tabasco

E-mail address: j_elemi@hotmail.com

Verónica García-Martínez: Universidad Juárez Autónoma de Tabasco

E-mail address: veronica.garcia@ujat.mx 